\title{
Green growth in Vietnam: policies and challenges
}

\author{
Nguyen An Dinh ${ }^{1, *}$, and Gang Chen ${ }^{2}$ \\ ${ }^{1}$ Viet Nam University of Traditional Medicine, No. 2, Tran Phu St., Ha Dong Dist., 10000, Hanoi, \\ Vietnam \\ ${ }^{2}$ Western University of Sydney, Locked Bag 1797 Penrith, NSW 2751 Australia
}

\begin{abstract}
Green growth is an important content of sustainable development as well as a process which included a combination between socio-economic development and environmental protection that meet the needs of current generation but not have any affect to future generations. Being implemented in Vietnam for many years, Green growth activities have achieved initial positive results, but also posed some practical challenges. This article will analyze and reviews the overall implementation of green growth in Vietnam and the issues that need to be solved.
\end{abstract}

\section{Introduction}

Changing development approach toward "a green economy" is a new approach, however, from a long-term perspective; this is a suitable approach for the general growth trend of the global economy.

With the Integration trend and sharing economic development experiences, especially, from 1945 till now, although, the world economy has achieved many accomplishments, many economic models in this period is based on a "brown" economy model, in which, the economy exploits and uses too much energy from fossil fuels and other natural resources, creating many damages for the environment such as air pollution, water pollution, ocean pollution, soil erosion, forest loss, and biological diversity loss. It is said that the old way of economic development, which has resulted in too much greenhouse gases emission such as $\mathrm{CO} 2, \mathrm{SO} 2, \mathrm{CH} 4$, etc., is the reason for climate change, which has occurred in a global scale, threatening human life and damaging economic activities. In order to change this situation, United Nations Environment Program (UNEP) has proposed a new approach of economic development, Green economy, which has received much support from many countries.

For special characteristics for Vietnam there was transition from "Central Planning Economy" toward "Socialist Oriented Market Economy". Since 1986, Vietnam started "Reformation and Gate-opening" (Doi moi and mo cua). Nowadays, Vietnam has escaped the poor countries group and entered middle-income group. After 30 years of renovation, Vietnam's economy has also paid the price for natural resources degradation and

\footnotetext{
* Corresponding author: dinhnguyenan1181@gmail.com
} 
environmental pollution. Lying within the global trend of economic development and adjustment of economic model and jobs structure, Vietnam has become a member of World Trade Organization (WTO), accordingly, economic development in Vietnam has to obey the general rules of commitments toward WTO about global integration. Moreover, Vietnam ranks among one of the five countries which are bear the most negative consequences of climate change, therefore, to strive for a "green economy" is a good choice. However, it is important to clearly recognize the opportunities and challenges in order to guide the development.

\section{Review the National Strategy regarding Green growth in Vietnam}

In Vietnam, the Prime Minister has issued a decision approving the National Strategy regarding Green Growth No. 1393/QD-TTg on Sep 25th 2012 and a National Action Plan regarding Green Growth in period 2014 - 2020 according to decision No. 403/QD-TTg of the Prime Minister on March 20th 2014. Nowadays, all Ministries, sectors and localities have begun to put these into practice. In the National Strategy regarding Green Growth, Vietnam's stances are:

- "Green Growth is one aspect of sustainable development, making sure the economy is developed quickly, effectively and sustainably, at the same time, contributing to the execution of the National Strategy regarding climate change.

- Green Growth must be by the people, and for the people, helping to create jobs, eradicate poverty, and improve quality of life for the people.

- Green Growth relies on increased investment into the preservation, development and effective use of the natural capitals, reduction of greenhouse gases, improve the quality of the environment, through these activities, stimulate economic growth.

- Green Growth is the work of the Party, of authorities of all levels, of all ministries, sectors and local regions; of all organizations, companies, social enterprises, social communities and all people."

Therefore, according to the viewpoint of the Green Growth strategy which has been issued in Vietnam, in order to achieve the goal of Green Growth, there are many things that must be done simultaneously; for example, effective use of natural recourses, environmental protection, poverty eradication, investment in preservation and development, greenhouse gas reduction. These works come from the efforts of all society, not only the authority but the people and business must fully understand and operate according to the goals of the strategy.

\section{Green growth policy of Vietnam in recent years}

In Vietnam, the Green Growth Program is concretized through the "National Strategy on Green Growth for the period of 2011 - 2020 and vision to 2050", which confirms: Green growth is the growth that based on the process of changing the growth model, restructuring for improving the efficiency and competitiveness of the economy through researching and applying advanced technology, developing modern infrastructure systems to effectively use natural resources, reducing greenhouse gas emissions, responding to climate change, contributing to poverty reduction and creating motive power for sustainable economic growth.

For sustainable development and green growth, the Government identified: Promoting the wider application of cleaner production; improving the efficiency of using natural resources, limiting the increase of pollution, protecting environmental quality, human 
health, ensuring sustainable development; Building a civilized, harmonious and friendly consumer culture with nature; developing the market of ecological products and community initiatives on production and sustainable consumption.

On September 25, 2012, the Prime Minister issued Decision No. 1393 / QD-TTg approving the National Strategy on Green Growth for the period of 2011-2020 and vision to 2050, which put forward two strategic tasks:

Firstly, greenizing production; implementing a clean industrialization strategy through reviewing and adjusting the existed sector plans; using economically and efficiently natural resources; encouraging the development of green technology and agriculture.

Secondly, greenizing lifestyles and promoting sustainable consumption; Combining traditional lifestyle with modern civilized facilities.

Green growth strategy is an important legal basis to develop policies related to green economy of Vietnam in near future Changing the green growth model has become viewpoint of the Communist Party of Vietnam as well as the consistent policy of the Government. It is also a basic content of the current development direction in Vietnam.

On March 20, 2014, the Prime Minister issued Decision No. 403 / QD-TTg approving the Action Plan of the National Green Growth for the period 2014-2020, in which, 4 topics were proposed, include: (1) Building institutions and local green growth plans; (2) Reducing the emissions of greenhouse gas and promoting the using of clean and renewable energy; (3) Greenizing production; (4) Greenizing lifestyle and sustainable consumption.

\section{Positive changes in the implementation of the Green Growth Strategy}

According to the 5-year report on the implementation of the Green Growth Strategy of the Ministry of Planning and Investment, there have been many positive results of the making policies to the public's awareness about green growth:

Firstly, establishing a system of legal documents for the implementation of green growth.

On June 3, 2013, Central Committee of CPV issued Resolution No. 24 / NQ-TW on response proactively to climate change, strengthening management to natural resource and environmental protection. This Resolution has the tasks: focus on promoting the transformation of the growth model that associated with restructuring the economy towards green growth and sustainable development.

The National Assembly has also promulgated, or supplemented, amended a number of laws related to green growth such as: Law on using Energy economically and Efficiently; Law on Natural Disaster Prevention; Law on Environmental Protection (amended); Hydrometeorology Law. Some new legal documents have been made to promote the implementation of activities which related to green growth. Specifically:

- In industrial field: Planning of electricity industry, power plants, industries and subsectors, especially which have strong impacts on the environment for sustainable development, using natural resources economically, controlling pollution and managing waste efficiently. Especially, the Renewable Energy Development Strategy has been made to 2030 with a vision to 2050; Making a legal framework for using energy in production and life economically and efficiently;

- In the field of agriculture: Law on Irrigation, Fisheries Law, Law on Forestry and the guiding documents and regulations on the "green" standards for agricultural, forestry and fishery production that were issued and applied which have effects for production and business.

- In the field of construction: Construction Industry has issued Action Plan for reducing the emissions of greenhouse gas in cement production to 2020 and orientation to 2030; 
National Urban Upgrading Program for the period of 2009 - 2020; National strategy for management of solid waste until 2025 with a vision to 2050; Vietnam green growth for urban development plan to 2030; Regulations on urban targets for green construction...

- In the field of transportation: In response to the Green Growth Strategy, together with other ministries, the Ministry of Transport have issued action plans to reduce CO2 emissions in Vietnam aviation activities in the period of 2016-2020.

Secondly, making a plan for actions of green growth. Through the making and promulgating active plan for green growth of ministries and localities, institutional improvement activities and implementation of the Green Growth Strategy are implemented. It is show that by the end of 2018 there are seven ministries have issued the Green Growth Action Plan. Until now, the whole country has 34 provinces and the Central Government cities making and implementing provincial level Green Growth Action Plans.

Thirdly, reduce the intensity of emitting greenhouse gas and increasing the rate of using renewable energy. The implementation of solutions to reduce the emissions of greenhouse gas have been widely implemented in all fields. According to the Institute of Energy, Ministry of Industry and Trade, Vietnam has reached 5.65\% of saving energy in the period of 2011 - 2015, which equivalent to the total saving energy of nearly 11.3 million tons of oil (TOE). The intensity of energy in industries which consume much energy is decreasing, such as: Steel industry decreased by $8.09 \%$; cement decreased by $6.33 \%$; textile fibers decreased by $7.32 \%$.

Fourthly, strengthening the greenizing production activities. The content of greenizing production is to implement a strategy of "clean industrialization" through reviewing and adjusting existing sectoral plans, using natural resources economically and efficiently, encouraging development of green industry and agriculture with technologies, equipment, etc., to ensure environmental principles, investment for developing natural capital, preventing and treating pollution.

\section{Difficulties and challenges}

Besides the positive results, the implementation of the Green Growth Strategy in Vietnam still faces many difficulties and specific challenges:

Firstly, the awareness of some ministries, agencies and local authorities on the Green Growth Strategy are unclear. As mention above, by the end of 2018, only 7 ministries and $34 / 63$ provinces and cities issued plans to implement the Green Growth Strategy. It is show that concretizing the National Green Growth Strategy is not a mandatory task that needs to be prioritized by ministries, and localities.

Secondly, the projects in relation to the National Green Growth Strategy have been implemented by ministries and localities, are based on the financial and technical support of international organizations, Non-governmental organizations which have not derived from capacities of these institutions.

Thirdly, at present, there are still conflicts and overlapping goals among strategies: Sustainable development strategy; National strategy on responding climate change; Green growth strategy, etc.,

Fourthly, the resources for implementing the Green Growth Strategy are currently unclear, especially in the context of economic recession and the reductions of public investment.

Fifthly, although there are integrations of the Green Growth Strategy into local socioeconomic development plans but many localities in Vietnam are facing the challenges because of the lack of specific and feasible solutions for the situations of them. 


\section{Solutions for promoting the implementation of the Green Growth Strategy in Vietnam}

For promoting the implementation of the Green Growth Strategy, Vietnam should focus on the followings:

Firstly, completing the framework of plan and investment policies. It is necessary to complete and issue a set of indicators for measuring national green growth of Vietnam. So, there are some green growth indicators need to be added to the system of socio-economic development targets. Preparing for completing and applying green growth targets to the 5year socio-economic development plan (2021-2025).

Secondly, complete the framework of financial policy for green growth. Making a framework to allocative and management national budget policies for the implementation of the Green Growth Strategy. Besides, completing the framework of financial policy (including: Taxes, fees, funds, sanctions, green criteria, sustainable development for businesses, etc.,) which relate to promoting the implementation of the Green Growth Strategy; making mechanisms to support private sector in preparing and implementing for green growth projects.

Thirdly, researching and issuing norms, standards and guidelines of green technics. Branches and localities continue to map out a route for implementing activities of green growth, raising awareness of green growth for leaders of state management agencies, branches, localities and enterprises.

\section{Conclusion}

The change of development method towards "green economy" is a new approach. However, in the long term it is the appropriate approach to the development trend of the global economic system. Moreover, Vietnam is a later developing country, therefore, to shorten the development gap and to access to a modern economy, the development of a green economy should be the first orientation. But the development model and the industry structure matching with a "green economy" in the context of Vietnam's development need to continuously studied and perfect, learn the lessons of the previous nations who implemented green economies for the appropriate steps.

\section{References}

1. The Prime Minister of Vietnam. National Strategy on Green Growth for the period of 2011 - 2020 and vision to 2050 (2012)

2. The Prime Minister of Vietnam. National Action Plan regarding Green Growth in period 2014 - 2020, Decision No. 403/QD-TTg on March $20^{\text {th }} 2014$ (2014).

3. The Prime Minister of Vietnam. Target program to respond to climate change and green growth. Resolution No. 73/NQ-CP on August 26 ${ }^{\text {th }}, 2016$ (2016)

4. D. O'Rourke Journal of Vietnamese Studies, 1(1-2), 506-508 (2006) https://doi:10.1525/vs.2006.1.1-2.506

5. N.T. Thang, D.T.P. Anh, Waste Management and Resource Efficiency (Springer, Singapore, 2019). https://doi.org/10.1007/978-981-10-7290-1_27

6. T.V. Nguyen, M.H. Nguyen, Q.Le Van, Biophys Econ Resour Qual 3, 9 (2018). https://doi.org/10.1007/s41247-018-0044-5

7. P.D. Uy, N. Nakagoshi. Landscape Ecol Eng 3, 143-157 (2007). https://doi.org/10.1007/s11355-007-0030-3 
8. T.C.T. Dao, T.H. Nguyen Green Technologies and Infrastructure to Enhance Urban Ecosystem Services. SSC 2018. (Springer Geography. Springer, Cham, 2020). https://doi.org/10.1007/978-3-030-16091-3_26

9. T.T.M. Dieu Environ Dev Sustain 8, 229-249 (2006). https://doi.org/10.1007/s10668005-9016-1

10. UNEP. Towards a Green Economy: Pathways to Sustainable Development and Poverty Eradication - A Synthesis for Policy Makers, (2011) www.unep.org/greeneconomy. 